\title{
Pengaruh Pemberian Madu dari Lebah Apis mellifera, Apis cerana, dan Trigona sp. terhadap Beberapa Parameter Biokimia pada Mencit yang Diuji dengan Metode WFST
}

\author{
Mukti Priastomo', I Ketut Adnyana ${ }^{2}$, Sukrasno $^{3}$, dan Kusnaedi ${ }^{4}$ \\ ${ }^{1}$ Laboratorium Penelitian dan Pengembangan Kefarmasian "Farmaka Tropis", Fakultas Farmasi Universitas \\ Mulawarman, Samarinda, Indonesia \\ ${ }^{2}$ Kelompok Keahlian Farmakologi dan Klinis, Sekolah Farmasi, Institut Teknologi Bandung, Bandung, Indonesia \\ ${ }^{3}$ Kelompok Keahlian Bahan Alam, Sekolah Farmasi, Institut Teknologi Bandung, Bandung, Indonesia \\ ${ }^{4}$ Kelompok Keahlian Farmasi Olahraga, Sekolah Farmasi, Institut Teknologi Bandung, Bandung, Indonesia
}

Korespondensi: Mukti Priastomo

Email:mukti@farmasi.unmul.ac.id

Submitted: 10-10-2020, Revised: 15-12-2020, Accepted: 21-12-2020

\begin{abstract}
ABSTRAK: Lebah madu merupakan golongan serangga yang dapat menghasilkan madu. Produk madu ini dihasilkan dari nectar yang diolah oleh lebah madu sebagai cadangan makanan bagi koloni lebah madu. Komposisi kimia yang terkandung pada madu menjadikan produk alam ini memiliki manfaat yang banyak. Salah satunya adalah manfaat untuk meningkatkan stamina. Peningkatan aktivitas dapat menurunkan stamina dan menimbulkan kelelahan. Penelitian ini bertujuan untuk melihat perbedaan efek anti lelah dari tiga jenis madu yang banyak digunakan di Indonesia, yaitu madu Apis mellifera, Apis cerana, dan Trigona sp. Pengujian anti lelah dilakukan dengan mengukur efek anti lelah secara fisik dan biokimia terhadap hewan coba mencit jantan dengan menggunakan metode Weight-loaded Forced Swimming Test (WFST). Madu digunakan pada pengujian dengan pemberian oral menggunakan dosis 10,40 g/kg yang dilanjutkan dengan pengamatan waktu aktivitas serta uji biokimia darah dengan parameter glukosa darah, asam laktat, serta glikogen pada otot dan hati. Hasil penelitian menunjukkan bahwa ketiga jenis madu yang diujikan dapat memberikan efek anti lelah dibanding kelompok kontrol, dimana madu Apis cerana menunjukkan hasil yang lebih baik dari dua kelompok sampel lainnya.
\end{abstract}

Kata kunci: madu; swimming; glukosa; lebah

\begin{abstract}
Honey bees are a class of insects that can produce honey. This honey product is produced from nectar which is processed by honey bees as food reserves for the honey bee colony. The chemical composition contained in honey makes this natural product has many benefits. One of them is increase stamina. Increased activity can reduce stamina and cause fatigue. This study aimed to see the differences in anti-fatigue effects of three different types of honey that are widely used in Indonesia, namely Apis mellifera, Apis cerana, and Trigona sp. The anti-fatigue test was carried out by measuring the physical and biochemical anti-fatigue effects of male mice using Weight-loaded Forced Swimming Test (WFST). Honey was used in anti-fatigue testing with oral administration in dose of $10.40 \mathrm{~g} / \mathrm{kg}$, followed by observation of activity time and blood biochemical tests with parameters such as blood glucose, lactic acid, and glycogen in muscle as well as liver. The results showed that the three types of honey had an anti-fatigue effect compared to the control group, where Apis cerana honey showed better results than the other samples.
\end{abstract}

Keywords: honey; swimming; glucose; honey-bee 


\section{Pendahuluan}

Lebah madu adalah serangga keluarga Apidae yang menghasilkan madu sebagai hasil dari pengumpulan dan pengubahan nektar atau sekresi bagian suatu tanaman [1]. Secara umum, keluarga Apidae dikelompokkan menjadi dua, yakni genus Apis atau lebah madu bersengat dan genus Trigona atau lebah madu tidak bersengat.

Banyaknya spesies lebah madu, mempengaruhi produk madu yang dihasilkan. Perbedaan madu dapat ditinjau secara fisik dari warna, rasa, dan aroma. Selain itu, perbedaan madu juga dapat terlihat dari kandungan kimia penyusun madu. Secara umum, kandungan utama madu adalah fruktosa dan glukosa. Namun, madu juga memiliki kandungan lain yang berperan dalam mempengaruhi kualitas madu, yakni vitamin, protein, dan mineral serta mengandung alkaloid, flavonoid, dan komposisi kimia lainnya [2].

Adanya kandungan kimia yang cukup banyak dan beragam pada madu memungkinkan madu memiliki banyak khasiat [3]. Salah satu khasiat madu yang diyakini secara umum adalah sebagai penambah stamina. Adanya konsentrasi fruktosa dan glukosa yang tinggi, dipercaya sebagai komponen utama penambah stamina dalam aktivitas. Bertambahnya stamina dapat dikatakan sebagai penambahan energi. Pengeluaran energi memerlukan proses biokimia yang kompleks. Energi yang diperlukan berupa adenosine triphosphate (ATP). Energi dalam bentuk ATP ini akan dihidrolisis menjadi adenosine diphosphate (ADP). Karena jumlahnya yang terbatas di dalam tubuh, maka efek yang ditimbulkan adalah lelah [4].

Parameter lelah dikarenakan adanya pembentukan asam laktat. Produksi asam laktat sebagai metabolit diperoleh melalui jalur metabolisme anaerob memanfaatkan glukosa dan glikogen melalui proses glikolisis tanpa $\mathrm{O}_{2}$. Adanya penumpukan asam laktat yang tak termetabolisme, dapat mengakibatkan terjadinya asidosis yang dapat mencetuskan rasa nyeri.

Tujuan dari penelitian ini adalah untuk mengetahui efek tiga jenis madu dari tiga spesies lebah madu yang berbeda (Apis mellifera, Apis cerana, dan Trigona sp.) terhadap peningkatan stamina dan efek anti lelah dengan melihat pengaruhnya terhadap proses biokimia pada jalur anaerobik. Pengujian dilakukan dengan model penelitian menggunakan hewan coba, yakni mencit jantan galur Swiss Webster yang telah diadaptasikan renang menggunakan metode uji Weight-loaded Forced Swimming Test (WFST).

\section{Metode}

\subsection{Alat dan Bahan}

Alat-alat yang digunakan antara lain water bath, spektrofotometer serapan atom, tanur, laminar air flow, centrifugation tube, semi automated Clinical Chemistry Analyser Vital Scientific (microlab $300^{\circledR}$ ), UV/Vis spectrophotometer DU 720 (Beckman Counter ${ }^{\circledR}$ ), Micropipet (Socorex ${ }^{\circledR}$ ), hot plate, timbangan gram digital, timbangan kilogram digital $\left(\mathrm{Kris}^{\circledR}\right)$, kolam renang mencit, gunting, restrainer, sonde oral, dan berbagai alat gelas laboratorium.

Bahan yang digunakan berupa madu dari spesies lebah Apis mellifera, Apis cerana, dan Trigona $s p$. Sampel madu diperoleh dari peternakan lebah madu di Kota Malang, Jawa Timur, Indonesia. Lebah madu telah dikonfirmasi di Sekolah Teknologi Biologi (SITH), Institut Teknologi Bandung (ITB), Indonesia. Uji karakteristik madu sesuai dengan Standar Nasional Indonesia (SNI) telah dilakukan di Fakultas Peternakan Universitas Padjadjaran Bandung. Bahan penelitian lainnya meliputi: timbal, tembaga, amonia encer, kloroform, asam klorida, pereaksi Dragendorf, pereaksi Mayer, serbuk magnesium, amil alkohol, besi (III) klorida, gelatin, eter, pereaksi Lieberman-Burchard, sediaan minuman berenergi yang mengandung caffein, lactate (liquid) reagent set (Pointe Scientific Cattalog L7596.50), alkohol, Anthrone Acs reagent 97\% (Sigma Aldrich ${ }^{\circledR}$ ), asam sulfat pekat, $\mathrm{KOH}$, dan aquades.

\subsection{Hewan coba}

Sebanyak dua puluh lima ekor mencit jantan galur Swiss Webster dengan berat antara 20-30 g 
ditempatkan di bawah kondisi laboratorium standar dan dipelihara pada siklus terang dan gelap alami serta memiliki akses ke makanan dan air. Hewan diaklimatisasi dengan kondisi laboratorium sebelum percobaan. Setiap hewan hanya digunakan satu kali. Protokol telah disetujui oleh komite etik Sekolah Farmasi Institut Teknologi Bandung dengan Surat Keputusan Komisi Etik Nomor 04/KEPHP-ITB/06-2013. Mencit dibagi secara acak menjadi lima kelompok ( $\mathrm{n}=5$ pada setiap kelompok). Kelompok kontrol diberikan satu $\mathrm{ml}$ air suling setiap hari selama tiga minggu. Semua sampel madu dari Apis mellifera, Apis cerana, dan Trigona sp. diberikan dengan dosis $10,40 \mathrm{~g} / \mathrm{kg}$ berat badan selama tiga minggu.

\subsection{Pengujian}

Pengujian ini menggunakan metode WFST dengan beberapa modifikasi [5]. Setelah pemberian oral terakhir lima mencit dikeluarkan dari masing-masing kelompok untuk latihan renang dengan beban konstan yang melekat pada ekor sesuai dengan $10 \%$ dari bobot badan mereka. Latihan renang dilakukan di kolam kaca $50 \mathrm{~cm} \mathrm{x}$ $50 \mathrm{~cm} \times 30 \mathrm{~cm}$ ) sedalam $20 \mathrm{~cm}$ dengan air dipertahankan pada $27 \pm 2^{\circ} \mathrm{C}$. Kelelahan ditentukan dengan mengamati hilangnya gerakan terkoordinasi dan kegagalan untuk kembali ke permukaan dalam waktu 10 detik, dan waktu berenang segera dicatat [5]. Pengukuran parameter uji dilakukan sebagai berikut:

a. Pengukuran asam laktat dilakukan menggunakan reagen lactate (liquid) reagent set (Pointe Scientific Cattalog L7596.50) dengan protokol uji sesuai dengan prosedur yang tertera pada wadah reagen.

b. Pengukuran kadar glikogen organ hati dan jaringan otot (M. gastrocnemius) pada bagian kaki belakang diambil lalu dikeringkan dalam oven pada suhu $50^{\circ} \mathrm{C}$ selama satu malam, lalu digerus dijadikan tepung. Masing-masing sampel diambil $25 \mathrm{mg}$ dan diekstraksi dengan $1 \mathrm{ml}$ laru$\tan \mathrm{KOH} 30 \%$ dan diinkubasi dalam penangas air mendidih selama 20 menit, lalu didinginkan. Ke dalam tabung sampel ditambahkan 1,5 $\mathrm{ml}$ etanol (95\%) dingin dan disimpan dalam suhu $4^{\circ} \mathrm{C}$ selama 30 menit. Untuk memisahkan endapan glikogen, sampel disentrifugasi dengan kecepatan 2500 rpm selama 20 menit. Endapan yang diperoleh diencerkan dengan 1 $\mathrm{ml}$ aquades. Ke dalam tabung yang telah diisi masing-masing $100 \mu \mathrm{l}$ sampel otot dan 100 $\mu \mathrm{l}$ sampel hati ditambahkan $3 \mathrm{ml}$ anthroneasam sulfat $0,2 \%(\mathrm{w} / \mathrm{v})$. Timbulnya warna hijau, menunjukkan larutan positif mengandung glikogen. Reaksi perubahan warna ini kemudian diukur absorbansinya dengan spektrofotometer pada panjang gelombang $620 \mathrm{~nm}$ dan kadar glikogen dihitung dengan cara membandingkan dengan kadar glikogen standar.

\subsection{Analisis data}

Data penelitian yang diperoleh kemudian diolah secara statistik dengan metode ANOVA pada taraf kepercayaan 95\% untuk mengetahui adanya perbedaan yang bermakna antara kelompok uji dengan kelompok kontrol dan kelompok pembanding.

\section{Hasil dan pembahasan}

Pengujian anti lelah menggunakan model hewan coba mencit jantan galur Swiss Webster. Pengujian anti lelah bertujuan untuk mengetahui apakah ketiga bahan uji memiliki pengaruh mengurangi rasa lelah sehingga dapat meningkatkan aktivitas gerak pada hewan uji mencit. Pengujian dimulai dengan menimbang berat badan hewan uji dan orientasi renang hewan coba untuk memastikan apakah hewan coba yang digunakan dapat berenang atau tidak. Metode pengujian yang digunakan adalah metode renang paksa atau Weight-loaded Force Swimming Test (WFST). Hewan coba diuji renang dengan paksa menggunakan penambah beban seberat $10 \%$ dari berat badan hewan uji [6].

Meskipun mencit bukan binatang air, bila dimasukkan ke dalam bak berisi air maka mencit akan berenang sekuat tenaga untuk bertahan. 
Pada aktivitas yang berat ini, ditambah adanya beban $10 \%$ dari berat badan hewan coba, maka energi yang diperlukan per unit waktu akan sangat meningkat dibandingkan dengan masa istirahat. Hal ini akan mengaktifkan metabolisme anaerobik di dalam sel otot untuk menghasilkan energi dan akan menghasilkan asam laktat intrasel.

Pemberian dosis kepada hewan uji didasarkan pada penggunaan normal pada manusia satu hari yakni $80 \mathrm{~g}$ yang dikonversikan sesuai berat badan hewan uji, sehingga didapat dosis pemberian 20,8 miligram untuk 20 g berat badan mencit. Bahan uji berupa madu tidak dapat diberikan secara oral langsung karena konsistensi madu yang kental sehingga dapat mengurangi jumlah madu yang diberikan. Oleh karena itu, sampel madu dilarutkan terlebih dahulu ke dalam aquadest. Agar mendapatkan dosis yang sesuai dengan perhitungan konversi kepada hewan uji, maka dilakukan pengukuran berat jenis pada ketiga sampel madu. Diperoleh data berat jenis madu Apis mellifera, Apis cerana, dan Trigona sp. masing-masing adalah 1,231; 1,301; dan 1,274 g/ ml. Masing-masing sampel tidak diujikan dengan dosis yang bervariasi dikarenakan penelitian ini bertujuan untuk mengetahui efek dari madu yang berbeda jenis. Oleh karena itu, ketiga jenis madu diberikan dengan dosis yang sama yakni 10,40 g/ $\mathrm{kg}$, sedangkan kelompok pembanding diberikan minuman berenergi yang mengandung kafein dengan dosis $50 \mathrm{mg} / \mathrm{kg}$. Sementara itu, kelompok kontrol hanya diberikan aquadest sebagai larutan pembawa madu.

Model penelitian WFST pada hewan sudah sesuai dengan model pengukuran anti lelah pada manusia [7]. Efek dari renang paksa ini akan menyebabkan kelelahan otot akibat adanya intensitas waktu yang lama. Faktor adanya kelelahan dapat terlihat dari durasi waktu aktivitas, menurunnya kadar glukosa darah, berkurangnya kadar glikogen sebagai cadangan energi, dan meningkatnya metabolit asam laktat dalam darah [8]. Untuk melihat adanya kemungkinan faktor berat badan hewan coba terhadap durasi waktu renang, maka dilakukan pengukuran berat badan setiap hari selama 21 hari. Hasil pengukuran berat badan hewan coba dapat dilihat pada Tabel 1 .

Tabel 1 menunjukkan peningkatan berat badan terjadi pada semua kelompok perlakuan. Peningkatan berat badan yang terjadi pada seluruh kelompok perlakuan menunjukkan hasil yang tidak berbeda signifikan antar semua kelompok $(p<0,05)$. Dari hasil ini diketahui bahwa sampel tidak memberikan pengaruh peningkatan berat badan. Adanya pengaruh peningkatan berat badan kelompok hewan golongan rodent terhadap waktu renang telah dikonfirmasi dalam penelitian oleh Hohl et al. [9]. Namun, dikarenakan tidak adanya perbedaan signifikan terhadap berat badan antar kelompok perlakuan, maka dapat dikatakan bahwa berat badan hewan coba pada penelitian ini bukan faktor yang mempengaruhi waktu renang hewan coba.

Tabel 1. Hasil pengamatan parameter berat badan mencit

\begin{tabular}{|c|c|c|c|c|c|}
\hline \multirow[t]{3}{*}{ Hari ke- } & \multicolumn{5}{|c|}{ Berat badan mencit (g) } \\
\hline & \multirow{2}{*}{ Pembanding } & \multicolumn{3}{|l|}{ Bahan uji } & \multirow{2}{*}{ Kontrol } \\
\hline & & MAM & MAC & MT & \\
\hline 0 & $29,44 \pm 2,03$ & $30,08 \pm 1,62$ & $30,34 \pm 2,66$ & $28,52 \pm 2,49$ & $29,72 \pm 1,69$ \\
\hline 21 & $31,02 \pm 2,38$ & $30,4 \pm 0,70$ & $30,78 \pm 2,60$ & $30,42 \pm 2,08$ & $29,56 \pm 2,53$ \\
\hline
\end{tabular}

Keterangan:

Nilai merupakan rerata \pm SD $(\mathrm{n}=5)$. Pembanding: sediaan minuman berenergi yang mengandung kafein, kontrol: aquadest, MAM: madu Apis mellifera 10,40 g/kg BB, MAC: madu Apis cerana 10,40 g/kg BB, MT: madu Trigona sp. 10,40 g/kg BB. 
Kelelahan yang terjadi pada hewan coba dengan metode WFST ditandai dengan hilangnya koordinasi otot hewan coba yang mengakibatkan hewan coba tenggelam. Ketidakmampuan hewan coba untuk tetap berada di atas permukaan air menandakan terjadinya kelelahan [10]. Upaya hewan coba untuk mempertahan diri berada di atas permukaan air dapat diukur dengan parameter waktu. Kemampuan mempertahankan energi di dalam tubuh hewan coba akan meningkatkan kemampuan bertahan hewan coba saat berenang. Pengukuran durasi waktu renang dilakukan selama empat kali dengan jeda waktu 7 hari. Hasil pengamatan dapat dilihat pada Tabel 2. Berdasarkan tabel tersebut terlihat bahwa seluruh kelompok perlakuan mengalami peningkatan durasi renang pada pengujian setiap minggu- nya. Kemampuan otot untuk beradaptasi akibat adanya aktivitas dimungkinkan terjadi pada seluruh kelompok perlakuan [11].

Walau terjadi peningkatan durasi renang yang sama pada seluruh kelompok perlakuan, namun terdapat perbedaan durasi waktu renang yang terlihat pada hari ke-21. Berdasarkan perhitungan statistik uji-t, pada sampel MAC menunjukkan perbedaan signifikan $(\mathrm{p}<0,05)$ dibanding dengan kelompok kontrol pada pengujian di hari ke-21.

Sebagai akibat adanya aktivitas fisik, maka tubuh akan mengalami perubahan reaksi biokimia [5]. Reaksi ini dapat berbentuk penurunan glukosa darah dan pengurangan kadar glikogen akibat penggunaan ATP sebagai sumber energi dan peningkatan kadar asam laktat sebagai bentuk hasil

Tabel 2. Hasil pengamatan parameter waktu renang mencit

\begin{tabular}{|c|c|c|c|c|c|}
\hline \multirow[t]{3}{*}{ Hari ke- } & \multicolumn{5}{|c|}{ Waktu renang (detik) } \\
\hline & \multirow{2}{*}{ Pembanding } & \multicolumn{3}{|l|}{ Bahan uji } & \multirow{2}{*}{ Kontrol } \\
\hline & & MAM & MAC & MT & \\
\hline 0 & $612 \pm 26$ & $624 \pm 32$ & $612 \pm 26$ & $624,00 \pm 32$ & $612 \pm 26$ \\
\hline 7 & $518 \pm 254$ & $972 \pm 213$ & $1044 \pm 138$ & $984,00 \pm 182$ & $684 \pm 187$ \\
\hline 14 & $996 \pm 403$ & $1392 \pm 486$ & $1476 \pm 490$ & $1692,00 \pm 307$ & $972 \pm 186$ \\
\hline 21 & $1260 \pm 639$ & $2040 \pm 485$ & $2168 \pm 372 *$ & $1824,00 \pm 192$ & $1212 \pm 248$ \\
\hline
\end{tabular}

Keterangan:

Nilai merupakan rerata \pm SD $(\mathrm{n}=5)$. Pembanding: sediaan minuman berenergi yang mengandung kafein, kontrol: aquadest, MAM: madu Apis mellifera 10,40 g/kg BB, MAC: madu Apis cerana 10,40 g/kg BB, MT: madu Trigona sp. 10,40 g/kg BB. *Menunjukkan perbedaan bermakna terhadap kontrol $(\mathrm{p}<0,05)$.

Tabel 3. Persentase penurunan kadar glukosa darah mencit

\begin{tabular}{|c|c|c|c|c|c|}
\hline \multirow[t]{3}{*}{ Hari ke- } & \multicolumn{5}{|c|}{ Persentase penurunan glukosa darah mencit } \\
\hline & \multirow{2}{*}{ Pembanding } & \multicolumn{3}{|l|}{ Bahan uji } & \multirow{2}{*}{ Kontrol } \\
\hline & & MAM & MAC & MT & \\
\hline 0 & $21,85 \pm 4,94$ & $18,31 \pm 17,19$ & $17,21 \pm 19,34$ & $22,11 \pm 13,71$ & $35,82 \pm 7,81$ \\
\hline 21 & $35,49 \pm 10,10$ & $10,08 \pm 8,96^{*}$ & $16,22 \pm 6,47^{*}$ & $15,50 \pm 5,92^{*}$ & $38,61 \pm 8,09$ \\
\hline
\end{tabular}

Keterangan:

Nilai merupakan rerata \pm SD $(n=5)$. Pembanding: sediaan minuman berenergi yang mengandung kafein, kontrol: aquadest, MAM: madu Apis mellifera 10,40 g/kg BB, MAC: madu Apis cerana 10,40 g/kg BB, MT: madu Trigona sp. 10,40 g/kg BB. *Menunjukkan perbedaan bermakna terhadap kontrol $(\mathrm{p}<0,05)$. 
metabolit akhir dari reaksi aktivitas anaerobik. Karenanya pada penelitian ini diukur juga kadar glukosa di dalam darah hewan uji. Glukosa berperan sebagai sumber energi dalam melakukan aktivitas [12]. Cadangan glukosa dalam darah yang cukup dapat mempertahankan kemampuan beraktivitas. Kekurangan glukosa dalam darah akan menurunkan aktivitas [13]. Hasil pengamatan persentase penurunan glukosa darah dapat dilihat pada Tabel 3.

Glukosa berperan sebagai sumber energi dalam melakukan aktivitas [12]. Cadangan glukosa dalam darah yang cukup, dapat mempertahankan kemampuan beraktivitas. Kekurangan glukosa dalam darah akan menurunkan aktivitas [13]. Hasil pengamatan persen penurunan glukosa darah dapat dilihat pada Tabel 3. Dari
Tabel 3, dapat dilihat bahwa pada hari ke-0 seluruh kelompok perlakuan mengalami penurunan kadar glukosa darah pasca renang. Namun pada hari ke-21 setelah pemberian sampel, kelompok uji menunjukkan hasil penurunan kadar glukosa yang berbeda dengan kelompok kontrol dan dibandingkan pada hari ke-0. Perbedaan ini mengindikasikan bahwa sampel uji dapat menjaga kadar glukosa darah, sehingga energi tidak cepat habis. Hasil uji statistik terhadap persen penurunan kadar glukosa menunjukkan adanya perbedaan bermakna $(\mathrm{p}<0,05)$ antara kelompok uji dibanding kontrol.

Ketersediaan glukosa yang cukup di dalam darah mengakibatkan tubuh tidak perlu merombak glikogen dalam jumlah banyak, sehingga cadangan energi berupa glikogen di organ hati dan ja-

Tabel 4. Kadar glikogen pada organ hati dan jaringan otot

\begin{tabular}{lll}
\hline \multirow{2}{*}{ Kelompok } & \multicolumn{2}{l}{ Glikogen $(\mathbf{m g} / \mathbf{g})$} \\
\cline { 2 - 3 } & Hati & Otot \\
\hline Pembanding & $101,23 \pm 9,08$ & $4,71 \pm 1,12$ \\
MAM & $168,1 \pm 39,09^{*}$ & $5,88 \pm 1,79$ \\
MAC & $145,02 \pm 37,10^{*}$ & $6,48 \pm 0,96$ \\
MT & $139,57 \pm 49,44^{*}$ & $7,29 \pm 2,61$ \\
\hline Kontrol & $102,08 \pm 12,45$ & $5,58 \pm 1,50$ \\
\hline
\end{tabular}

Keterangan:

Nilai merupakan rerata \pm SD $(n=5)$. Pembanding: sediaan minuman berenergi yang mengandung kafein, kontrol: aquadest, MAM: madu Apis mellifera 10,40 g/kg BB, MAC: madu Apis cerana 10,40 g/kg BB, MT: madu Trigona sp. 10,40 g/kg BB. *Menunjukkan perbedaan bermakna terhadap kontrol $(\mathrm{p}<0,05)$.

Tabel 5. Kadar asam laktat dalam darah mencit

\begin{tabular}{llllll}
\hline Hari ke- & \multicolumn{4}{l}{ Kadar asam laktat $(\mathbf{m m o l} / \mathbf{l})$} & \\
\cline { 2 - 5 } & \multirow{2}{*}{ Pembanding } & \multicolumn{2}{l}{ Bahan uji } & & Kontrol \\
\cline { 2 - 5 } & & MAM & MAC & $5,64 \pm 0,93$ & $6,59 \pm 0,88$ \\
\hline 0 & $4,92 \pm 1,29$ & $6,23 \pm 1,09$ & $6,07 \pm 1,38$ & $5,97 \pm 0,45$ & $7,67 \pm 0,76$ \\
\hline 21 & $6,94 \pm 1,00$ & $6,87 \pm 1,07$ & $6,63 \pm 0,98$ & 5,96 \\
\hline
\end{tabular}

Keterangan:

Nilai merupakan rerata \pm SD $(n=5)$. Pembanding: sediaan minuman berenergi yang mengandung kafein, kontrol: aquadest, MAM: madu Apis mellifera 10,40 g/kg BB, MAC: madu Apis cerana 10,40 g/kg BB, MT: madu Trigona sp. 10,40 g/kgBB. 
ringan otot masih tersimpan cukup banyak [14]. Hubungan antara ketersediaan glukosa di dalam darah dan cadangan glikogen dapat dilihat pada pengukuran kadar glikogen hati dan glikogen jaringan otot (M. gastrocnimeus). Hasil pengukuran dapat dilihat pada Tabel 4.

Glikogen berperan sebagai cadangan energi yang banyak disimpan di dalam organ hati. Glikogen merupakan sumber energi penting dalam aktivitas. Peningkatan glikogen sebagai cadangan energi di dalam hati dapat berkaitan dengan peningkatan aktivitas fisik. Pelepasan glikogen hati terjadi apabila sumber energi berupa glukosa di dalam darah menurun. Hal ini ditujukan untuk menjaga homeostasis glukosa di dalam darah [14].

Pemecahan glikogen di dalam hati untuk mensuplai energi selama aktivitas berlangsung dalam waktu milidetik. Habisnya glikogen juga sebagai penanda terjadinya kelelahan [15]. Hasil perhitungan statistik terlihat bahwa kadar glikogen pada organ hati kelompok uji berbeda bermakna bila dibanding dengan kelompok kontrol $(\mathrm{p}<0,05)$.

Glikogen berperan sebagai cadangan energi yang banyak disimpan di dalam organ hati. Glikogen merupakan sumber energi penting dalam aktivitas. Peningkatan glikogen sebagai cadangan energi di dalam hati dapat berkaitan dengan peningkatan aktivitas fisik. Pelepasan glikogen hati terjadi apabila sumber energi berupa glukosa di dalam darah menurun. Hal ini ditujukan untuk menjaga homeostasis glukosa di dalam darah [14]. Pemecahan glikogen di dalam hati untuk mensuplai energi selama aktivitas berlangsung dalam waktu milidetik. Habisnya glikogen juga sebagai penanda terjadinya kelelahan [15]. Hasil perhitungan statistik terlihat bahwa kadar glikogen pada organ hati kelompok uji berbeda bermakna bila dibanding dengan kelompok kontrol $(\mathrm{p}<0,05)$.

Pengukuran ketersediaan kadar glikogen juga dilakukan pada jaringan otot (M. gastrocnimeus). Hasil pengukuran kadar glikogen otot dapat dilihat Tabel 4. Hasil perhitungan statistik menunjukkan bahwa tidak terdapat perbedaan bermak- na antar kelompok perlakuan ( $\mathrm{p}<0,05)$.

Adanya aktivitas fisik yang besar dapat menimbulkan konsekuensi berupa peningkatan metabolit asam laktat. Metabolit asam laktat dihasilkan dari produk glikolisis karbohidrat pada aktivitas anaerobik, dimana terdapat aktivitas yang besar dengan rentang waktu yang cukup pendek [7]. Ambang laktat dapat dijadikan prediksi daya tahan selama aktivitas [16]. Secara seluler, penumpukan asam laktat di dalam otot akan menyebabkan asidosis intrasesluler dan dapat menimbulkan kelelahan. Asam laktat intraseluler otot akan berdifusi ke dalam darah dan meningkatkan kadar asam laktat plasma. Peningkatan kadar asam laktat dalam darah akan berbanding lurus dengan kemampuan bertahan saat berenang. Karena semakin berat aktivitas fisik yang dilakukan akan meningkatkan metabolisme anaerobik sehingga asam laktat meningkat [4].

Hasil pengamatan menunjukkan peningkatan kadar asam laktat dalam darah yang dapat dilihat pada Tabel 5. Secara statistik, kelompok bahan uji tidak memberikan pengaruh yang berbeda bermakna $(p<0,05)$ terhadap penghambatan kadar asam laktat.

Terjadinya peningkatan asam laktat dapat dihubungkan dengan durasi waktu renang golongan rodent terhadap peningkatan kadar asam laktat [17]. Bila dilihat kadar asam laktat pasca renang hasil penelitian pada hari ke-0 dibandingkan hari ke-21. Diketahui bahwa kelompok bahan uji tidak mengalami peningkatan kadar asam laktat yang signifikan, padahal durasi waktu renang kelompok uji meningkat pada hari ke-21 (lihat Tabel 2). Diduga kuat terjadi penghambatan produksi metabolit asam laktat pada kelompok uji. Sehingga terjadi penundaan kelelahan pada kelompok uji.

\section{Kesimpulan}

Bahan uji berupa madu dari spesies Apis cerana lebih unggul untuk mempertahankan kadar glukosa, glikogen dan ketahanan renang diban- 
ding dengan bahan uji madu dari spesiel Apis mellifera dan Trigona sp. Namun demikian tidak terjadi perbedaan yang signifikan diantara ketiga sampel tersebut.

\section{Ucapan terima kasih}

Ucapan terima kasih disampaikan kepada Pengelola Beasiswa Lembaga Penyalur Dana Pendidikan (LPDP) Kementerian Keuangan Republik Indonesia untuk Beasiswa Tesis yang diberikan.

\section{Daftar Pustaka}

1. Patra K. Lebah untuk Kesejahteraan Masyarakat. Jakarta: Ganeca Exact; 2011.

2. Singh MP, Chourasia HR, Agarwal M, Malhotra A, Sharma M, Sharma D, Khan S. Honey as complementary medicine: -a review. International Journal of Pharma and Bio Sciences. 2012;3(2):12-31.

3. Moniruzzaman M, Sulaiman SA, Khalil MI, Gan SH. Evaluation of physicochemical and antioxidant properties of sourwood and other Malaysian honeys: a comparison with manuka honey. Chemistry Central Journal. 2013;7(1):138.

4. Herwana E, Pudjiadi LL, Wahab R, Nugroho D, Hendrata T, Setiabudy R. Efek pemberian minuman stimulan terhadap kelelahan pada tikus. Jurnal Universa Medicina. 2005;24(1):8-14.

5. Yong-Xin X, Jian-Jun Z. Evaluation of anti-fatigue activity of total saponins of Radix notoginseng. The Indian journal of medical research. 2013;137(1):151-5.

6. Prasad MV, Khanum F. Antifatigue activity of ethanolic extract of Ocimum sanctum in rats. Research Journal of Medicinal Plant. 2012;6(1):37-46.

7. Xiang C, Guohai Z. Scavenging and anti-fatigue ac- tivity of Wu-Wei-Zi aqueous extracts. African Journal of Microbiology Research. 2011;5(32):5933-40.

8. Hargreaves M. Metabolic factors in fatigue. Sports Science. 2005;18(3):98.

9. Hohl R, de Oliveira RB, Ferraresso RL, Brenzikofer $\mathrm{R}$, Macedo DV. Effect of body weight variation on swimming exercise workload in rats with constant and size-adjusted loads. Scandinavian Journal of Laboratory Animal Sciences. 2011;38(3):145-54.

10. Jin HM, Wei P. Anti-fatigue properties of tartary buckwheat extracts in mice. International Journal of Molecular Sciences. 2011;12(8):4770-80.

11. Gossman MR, Sahrmann SA, Rose SJ. Review of length-associated changes in muscle: experimental evidence and clinical implications. Physical therapy. 1982;62(12):1799-808.

12. Srivastava S, Pathak PH. Dietary supplementation of garlic (Allium sativum) extract alters the glycogen deposition in liver and protein metabolism in gonads of male albino rats. International Journal of Research in Pharmaceutical Sciences. 2012;3(1):163-6.

13. Yildiz F, editor. Advances in food biochemistry. CRC press; 2009.

14. Marchand I. A Quantitative Analysis of the Subcellular Distribution of Human Skeletal Muscle Glycogen (PhD thesis). University of Guelph: Guelph, ON, Canada; 2001.

15. Shulman RG. Glycogen turnover forms lactate during exercise. Exercise and sport sciences reviews. 2005;33(4):157-62.

16. Goodwin ML, Harris JE, Hernández A, Gladden LB. Blood lactate measurements and analysis during exercise: a guide for clinicians. Journal of diabetes science and technology. 2007;1(4):558-69.

17. Voltarelli FA, Gobatto CA, De Mello MA. Determination of anaerobic threshold in rats using the lactate minimum test. Brazilian Journal of Medical and Biological Research. 2002;35(11):1389-94. 